\title{
Collaborative Innovation: The Only Way for the Development of Ideological and Political Education of Vocational College Students
}

\author{
Yan Ning \\ Hunan Vocational Institute of Safety Technology, Changsha, 410021, China
}

\begin{abstract}
Keywords: Higher vocational; Ideological and political education; Collaborative innovation; Development; Path
\end{abstract}

\begin{abstract}
With the further implementation of quality education, higher vocational education occupies a more and more important position in the national education system and takes on task of cultivation of high-quality talents who have the knowledge of national construction, management, and production for socialism. Ideological and political education is an integral part of educations in colleges and universities, which is equally important for higher vocational education. In recent years, higher vocational education has yielded a series of results in the ideological and political education, while it also encountered a lot of problems. Based on this background, this paper discusses the path of development of ideological and political education of vocational college students under the perspective of collaborative innovation.
\end{abstract}

\section{Introduction}

The transformation of society for talents in recent years makes skilled talents get the favor of enterprise than before. As main base for cultivation skilled talents, higher vocational colleges conveniently achieved rapid development in recent years. Higher vocational education has achieved excellent results whether in quantity or quality. However, as an important part of higher vocational education, ideological and political education has not substantially improved in such higher vocational colleges that could not meet needs of high quality and skilled talents. Collaborative innovation system of ideological and political education is a new concept issued according to the present situation in higher vocational colleges, which is conducive to ideological and political education of higher vocational college to adapt to the changes of the times and health growth of higher vocational college students.

\section{Overview of Collaborative Innovation}

Collaborative innovation theory was first presented in the field of researching of international innovation in 1970, which refers to an innovation created by innovative subject contacts with other subjects, aiming at promoting innovation activity by use of idea of collaboration. As a new organizational model, collaborative innovation puts research institutions of universities, governments and businesses as core of innovation and puts financial institutions, innovation platforms, agencies as auxiliary factors to conduct multifactorial innovation model, aiming at promoting common development of the various elements and deepening cooperation and resources integration between the various elements, achieving better use of resources.

\section{The Need for Applying of Collaborative Innovation in Ideological and Political Education of Vocational College Students}

\section{Enhance Effective Cooperation and Communication between the Bodies}

Application of collaborative innovation idea in development of ideological and political education of vocational college students can effective motivate all resources that are benefit for conducting ideological and political education in higher vocational colleges and put full-scale development of university students as development direction in higher vocational colleges. Ideological and political 
education in higher vocational colleges is not only the function of Ideological and Political Education Department of higher vocational colleges, but also plays the role of the relevant government departments and the students' study enthusiasm. Collaborative innovation system can coordinate relationship of such bodies effectively. For ideological and political education in higher vocational colleges, the ideological and political workers are the main implementers who conduct ideological and political education shall obtain maximum support from related departments of universities and governments and mobilize resources for such activity according to actual situation of students.

\section{Enhance Organic Integration and Development of All Aspects}

Application of collaborative innovation idea in development of ideological and political education of vocational college students are benefit for coordinating cooperativity and symbiosis of each part of ideological and political education. speaking from the collaborative innovation management concept, the effective use of collaborative innovation management in higher vocational colleges can effective coordinate from multiple steps like teaching contents, educational objectives, educational method and evaluation mechanisms and so on to promote development of effective coordination of each parts. We shall further mobilize initiatives of each part from most powerful target and give full play to the advantages of collaborative innovation. We shall coordinate relations of each part to launch a foundation for promoting effective and coordinated development.

\section{Strengthen Compatibility and Propulsion of Each Field}

Application of collaborative innovation idea in development of ideological and political education of vocational college students are benefit for multidisciplinary collaborative innovation and development of ideological and political education and also involves teaching domains, including innovation education development pattern, innovation education method, innovation educational contents and so on. Such fields and collaborative innovation work in fields shall be promoted in ideological and political education work of colleges and universities. For educating people, we shall use functions of ideological and political education with administration, professional teachers, and outstanding college students as participation people to give full play to the idea of educating people. Selecting a scientific and rational educational method meets needs of students for ideological and political education via introducing innovation method of ideological and political education and combing actual condition of colleges and universities. In addition, pertinence of ideological and political education shall be enhanced and scientificity of ideological and political education shall be satisfied. For content of ideological and political education, characteristics of education shall be shown and student's personality shall be considered, that is, achieving management objectives of collaborative innovation shall be guide students in subjective aspect and select relative scientific teaching content.

\section{Ideological and Political Education Development Path of Vocational College Students Based on Collaborative Innovation}

\section{Establish Collaborative Innovation Ideas}

To promote educational ideology of development of educational innovation is basis for achieving all innovations. For ideological and political education in China, the educational ideology shall be changed from breaking through the traditional way of education, forming open concept, management ideas and conforming objectives and so on, which can further promote healthy growth of college students; meet needs of self-development and achieve common development and progress of colleges and students in educational value. Because we ignore the consistency principle of bodies participating in education fundamentally, rapid growth of collaborative innovation of ideological and political education could not be promoted fundamentally. In collaborative innovation management process, open view shall be insisted in some traditional educational methods, aiming at preventing phenomenon of mutual isolation between departments and members. In addition, the objectives of innovative development shall be grasped from many aspects especially in the process participated by college students. We take innovation as the core; integrate and manage resources of ideological and 
political education in colleges and universities; further optimize the content of ideological and political education system and change personnel training mode in colleges and universities.

\section{Establish Internal and External Collaborative Innovation Mechanisms}

Establish internal collaborative innovation mechanism

The cultivation of ideological and ethical standards of college students is a long-term process, which is simple to achieve and is growth and accumulated in universities and colleges. Therefore, ideological and political education of students is a long-term and complex project, which requires higher vocational colleges conduct good ideological and political education via combining collaborative innovation concept of ideological and political education of university students according to their own development and different characteristics of different students, rule of ideological and political education and characteristics of higher vocational colleges. Collaborative innovation management system of ideological and political education of university students coordinates and manages development situation of teachers via establishing work force of ideological and political education of university students. The formed work force of ideological and political education of university students shall give full play its role to improve leadership and management mechanism and further conduct objective of innovation management. The value of dominant education and subconscious education shall be realized and effectiveness of ideological and political education shall be further improved.

Establish city-wide higher vocational colleges collaborative innovation mechanism

In order to promote collaborative and effective development of ideological and political education of university students, management work for it shall be conducted based on development of higher vocational colleges, promoting sharing resources and share experience of ideological and political education of university students and enhancing quality of the talents cultivation. The cause of ideological and political theories of city-wide higher vocational colleges shall establish "hand in hand" base project, carrying out teaching activities in regular time and sharing teaching experience to further improve effectiveness of ideological and political education. Collaborative innovation of city-wide higher vocational colleges' ideological and political education shall establish ideological and political theory course and shall include all involved teaching contents like ideological and political education of university students, psychological health education and health and safety education, etc.. Education authorities shall constantly establish collaborative innovation management mechanism of colleges' ideological and political education in city wide and improve ideal and moral quality of college students with times.

Focus on Establishment of Collaborative Innovation Education System, Evaluation Mechanisms

The core work of ideological and political education is to train personnel. The healthy growth of college students shall be achieved through establishing perfect education system. Related fields at home and abroad shows that establishment of education mode shall be made efforts by department of colleges, staffs and students as well as combined other factors of social institutions and families. In other words, a mature education mechanism requires many aspects involve in and college education quality and education quality shall be guaranteed in collaborative process. Collaborative innovation evaluation system shall be built based on collaborative activities and achieve the expected objective from perspective of implementation. Evaluation mechanism for ideological and political education shall insist on human-oriented and focus on overall development of students and combine feedback with evaluation during implemented evaluation as well as combine ideological and political education and student demand, improve and optimize situation faced by ideological and political education from the feedback mechanism.

\section{Establish Collaborative Innovation Platform}

In the process of collaborative innovation of ideological and political education, the involved contents are mainly related with national economy and people's livelihood project. In order to achieve effective objective of collaborative innovation, science and technology innovation platform covering any aspect shall be built and close cooperate with related departments. By using of high level of creative platform, shared resources and open resource shall be carried out that will further promote 
main focal points of collaborative creation. We should adopt a combination of theory and practice-oriented way and pay more attention on function of second classroom, which can give the method to build collaborative innovation platform and innovate contemporary college students' ideological and political education carrier. For example, adopting the diversified social practice activities can innovate method of ideological and political education of college students and enhance effectiveness of ideological and political education of college students, realizing objective of ideological and political education. The main idea that is most suitable for development of college students shall be found out by innovation of social practices and methods, which is one of key steps of ideological and political education. College students have the ability to quickly adapt to the environment shall be further cultivated through combination theory with practice, which help them to strengthen understanding of theoretical knowledge; to improve their moral qualities; to give full play to their talents and to serve society better.

\section{Set Up Collaborative Innovation Team}

In the process of realization of collaborative innovation, setting up team is basis for realization of collaborative innovation and guarantee of college students' ideological and political education carrier innovation. The carrier of college students' ideological and political education is innovation, which requires theoretical innovation and other collaborative innovation capabilities of bodies like executive force, influence and research capabilities, etc.. All these factors realized through setting up a collaborative innovation team who conducts optimization and management of structure of each body and lays a solid foundation for innovation of ideological and political education. For carrying out ideological and political education in colleges and universities, the key to setting up collaborative innovation carrier of ideological and political education is to optimize the team, manage team and improve collaborative innovation management ability of each body; to pay more attention on cultivation and playing innovation management capabilities and other capacities, aiming at doing well collaborative innovation management and giving full play to effectiveness of the ideological and political education.

\section{Strengthen Collaborative Innovation Network Construction}

Network construction of collaborative innovation platform construction of ideological and political education plays a critical role. First is to prepare for construction network platform. The major work is responsible and management of maintenance and construction work of ideological and political education theory with the purpose of construction of digital platform for university teachers and students to learn from each other and mutual study. Second is to construct campus network platform. For example, Party Committee Propaganda and Education Department, Employment Guidance Center, Youth League Committee and Education Department and others shall have complete network platform. Ideological and political theory course shall have online courses education resources and related departments shall have related website platforms, etc.. Campus network shall be optimized and integrated from its contents, which shall convenient for students to access. Third is to set up collaborative innovation platform and off-campus resources network platform. For example, related ideological and political education websites at national level, province level and municipal level shall be constructed as well as collaborative innovation platform shall be set up, aiming at forming a new pattern of ideological and political education that accepted by whole society.

\section{Conclusion}

In summary, the new direction of collaborative innovation mechanism for ideological and political education is in line with the development concept of ideological and political education and is also objective requirement in such era for talents and an inevitable trend in the society. Putting collaborative innovation mechanism as a new research topic and new development direction of higher vocational colleges is benefit for higher vocational colleges selecting useful resource in conducting vocational education for academic, professional, management, coordination. The 
ideological and political education level of higher vocational colleges and students' ideological level can be improved through integration of such resources.

\section{References}

[1] Wu Jing. Discuss Collaborative Innovation System of Ideological and Political Education. Modern Communication, 2014, (03): 223.

[2] Li Junsheng. Innovative System and Mechanism Promotes Collaborative Innovation of Financial Higher Education. China Higher Education,2012,(22):23-25

[3] Wang Haijian. Cultivation of College Students' Collaborative Innovation Ability based on Idea of Collaborative Innovation. Journal of China University of Petroleum,2012,(03):105-108

[4] Zheng Shizhu. Orientation and Mechanism of Local Colleges and Universities in Collaborative Innovation Chinese University Technology Transfer, 2013, (04): 22-23. 